\title{
DNA extraction from sea anemone (Cnidaria: Actiniaria) tissues for molecular analyses
}

\author{
S.M. Pinto ${ }^{1}$, F.M.C. Fernandes-Matioli ${ }^{2}$ and E. Schlenz ${ }^{1}$
}

\begin{abstract}
A specific DNA extraction method for sea anemones is described in which extraction of total DNA from eight species of sea anemones and one species of corallimorpharian was achieved by changing the standard extraction protocols. DNA extraction from sea anemone tissue is made more difficult both by the tissue consistency and the presence of symbiotic zooxanthellae. The technique described here is an efficient way to avoid problems of DNA contamination and obtain large amounts of purified and integral DNA which can be used in different kinds of molecular analyses.
\end{abstract}

\section{INTRODUCTION}

Sea anemones (Anthozoa: Actiniaria) are simple askeletal polyp animals, and a very diverse, ecologically important group of organisms (Schick, 1991). In spite of the many techniques that have been developed, the isolation of template DNA for PCR (Saiki et al., 1988) amplified from individual, small organisms can be difficult. Recently, DNA-based techniques have been used to determine the relationship of the Cnidaria to other metazoa and to examine relationships within the Cnidaria (e.g., Hori and Satow, 1991; Christen et al., 1991; Bridge et al., 1992; 1995; Chen, et al., 1995; Beagley et al., 1995; Veron et al., 1996; France et al., 1996; Odorico and Miller, 1997; Romano and Palumbi, 1997). Such approaches are elucidating long-standing controversies about relationships within the Cnidaria.

There are few techniques available for the extraction of DNA from sea anemone species (e.g., Wolstenholme, 1992; Pont-Kingdon et al., 1994; Finnerty and Martindale, 1997; Fautin and Smith, 1997) and these studies followed standard protocols previously described for other metazoan organisms (e.g. those of Wolstenholme and Fauron, 1976; Shure et al., 1983; Winnepenninckx et al., 1993; Folmer et al., 1994).

We have had success in obtaining good DNA templates using an optimization of the protocol described by Chen et al. (1995) to extract and subsequently amplify DNA from sea anemone specimens. The total DNA extracted was used as a template in polymerase chain reaction (PCR) experiments. The nuclear DNA was analyzed using the single primer amplification reaction technique (SPAR) (Gupta et al., 1994). These pilot experiments were carried out using the following species: Aiptasia pallida Verrill, 1864, Bellactis ilkalyseae Dube, 1983, Anthothoe chilensis (Lesson, 1830), Tricnidactis errans Pires, 1988, Haliplanella lineata (Verrill, 1869), Anthopleura krebsi Duchassaing \& Michelotti, 1860, Carcinactis dolosa Riemann-Zürneck, 1975, Paratelmatactis sp. (Pinto, S.M., unpublished data) and one species of corallimorpharian, Discosoma carlgreni (Watzl, 1922).

This article reviews the published literature and suggests a feasible DNA extraction method to obtain large amounts of pure and integral DNA for molecular analyses.

\section{RESULTS}

\section{DNA extraction}

We unsuccessfully attempted to extract DNA from sea anemones using previously published protocols. We then optimized the protocols by including some important additional steps involving careful adjustments in tissue maceration, followed by optimization of the concentrations of proteinase $\mathrm{K}$ and by modification of the standard phenol:chloroform extraction techniques.

Total genomic DNA was extracted from pieces of $100 \%$ ethanol-preserved sea anemones. For most specimens small pieces (approximately 0.5 to $1.0 \mathrm{~cm}$ ) of tissue from the pedal disc were used, which avoided possible amplification of the zooxanthellae DNA (Fautin and Smith, 1997). In all steps, shaking was for $15 \mathrm{~min}$ and centrifugation for $4 \mathrm{~min}$ at $6500 \mathrm{rpm}$, except in the third step that centrifugation was at $13.000 \mathrm{rpm}$. Prior to extraction the tissue fragments were placed in an Eppendorf tube and incubated at $35^{\circ} \mathrm{C}$ for $2 \mathrm{~h}$ in order to withdraw excess etha- 
nol. In step one, small pieces of tissue were ground into powder under liquid nitrogen and then placed in a final volume of $400 \mu \mathrm{l}$ of lysis buffer (10 mM Tris-HCL, pH 8.0, containing $0.25 \mathrm{M}$ EDTA, $\mathrm{pH} 8.0,2 \%(\mathrm{w} / \mathrm{v})$ sodium dodecyl sulfate, SDS). In step two, RNAse was added to a final concentration of $0.6 \mathrm{mg} / \mathrm{ml}$ and the sample was incubated for $30 \mathrm{~min}$ at $37^{\circ} \mathrm{C}$ in order to eliminate any RNA molecules. After that, proteinase $\mathrm{K}$ was added to a final concentration of $1 \mathrm{mg} / \mathrm{ml}$ and the mixture incubated for $72 \mathrm{~h}$ at $37^{\circ} \mathrm{C}$. After incubation an equal volume of phenol was added to the sample, which was then shaken and centrifuged. Approximately $360 \mu \mathrm{l}$ of the supernatant solution was then transferred to a clean tube and an equal volume of phenol added. Shaking and centrifugation were performed using the same conditions as above and $340 \mu \mathrm{l}$ of the supernatant was transferred to a new tube with an equal volume of chloroform:isoamylalcohol (24:1) and gently shaken before centrifugation. In step three, $300 \mu \mathrm{l}$ of the supernatant was transferred to a new tube containing $30 \mu \mathrm{l}$ of $6 \mathrm{M} \mathrm{NaCl}$ and gently stirred. The DNA was precipitated with 2.5 volumes of very cold absolute ethanol and the samples centrifuged for $4 \mathrm{~min}$ at $13.000 \mathrm{rpm}$. The supernatant was drained off and the pellet was washed with $70 \%$ ethanol and air-dried for $24 \mathrm{~h}$ with the tube inverted. The samples were resuspended in an appropriate volume of TE buffer (10 mM Tris-HCL, $\mathrm{pH} 8.0$, and $1 \mathrm{mM}$ EDTA) and incubated at $37^{\circ} \mathrm{C}$ for at least $48 \mathrm{~h}$, until completely soluble.

DNA was quantified in a spectrophotometer (Itachi model U-2000), the mean purity value was $1.8 \pm 0.1$ and extracted DNA concentration was $300-1.400 \mathrm{ng} / \mu \mathrm{l}$. The integrity of the extracted DNA was checked using $2 \mu \mathrm{l}$ of each sample on a $1.0 \%$ agarose gel stained with ethidium bromide. Figure 1 shows that the samples presented no signs of degradation. Figure 1 (upper half, lanes 6-9) also shows four unsuccessful DNA extractions, where samples were incubated $\left(24 \mathrm{~h}\right.$ at $\left.37^{\circ} \mathrm{C}\right)$ in the presence of proteinase $\mathrm{K}$.

DNA extracted from sea anemone samples was used as a template in PCR amplifications with the SPAR technique (Gupta et al., 1994). The tetranucleotide repeat primers used were 16 bases long. A variety of primers were assayed with the most informative outcomes from $(\mathrm{GACA})_{4}$.

In a study of the population structure of Actiniaria species being undertaken by S.M. Pinto and her colleagues, $(\text { GACA })_{4}$ is being used as a molecular marker under the name Micro 5.

\section{PCR reactions}

DNA(1 ng) was amplified in a total volume of $30 \mu \mathrm{l}$ containing $10 \mathrm{mM}$ Tris $\mathrm{HCl}, \mathrm{pH} 8.4,0.5 \%$ nonidet $\mathrm{P}-40,50$ $\mathrm{mM} \mathrm{KCl}, 5.0 \mathrm{mM} \mathrm{MgCl}{ }_{2}, 100 \mu \mathrm{M}$ each of dNTP (dGTP, dATP, dCTP and dTTP), 5 pmol (GACA $)_{4}$ primers and 1.25 units of TaqDNA polymerase (Life Technologies). Amplifications were performed in a Perkin Elmer TC1 thermocy- cler for 35 cycles. The first 5 cycles consisted of $45 \mathrm{~s}$ at $94^{\circ} \mathrm{C}, 60 \mathrm{~s}$ at $51^{\circ} \mathrm{C}$, and $60 \mathrm{~s}$ at $72^{\circ} \mathrm{C}$. The final 30 cycles consisted of $45 \mathrm{~s}$ at $92^{\circ} \mathrm{C}, 60 \mathrm{~s}$ at $48^{\circ} \mathrm{C}$, and $60 \mathrm{~s}$ at $72^{\circ} \mathrm{C}$. All products were visualized on a $1.4 \%$ agarose gel stained with ethidium bromide (Figure 2). Negative controls lacking sea anemone DNA were included in PCR assays to monitor any possible contamination (Palumbi, 1996).

\section{DISCUSSION}

The systematics of sea anemones is currently based on only a few morphological characters (see McCommas, 1991; Fautin and Smith, 1997), and may potentially improve the use of molecular characteristics for clarifying phylogenetic relationships among genera and species. The utility of DNA molecular markers for addressing evolutionary questions in sea anemones has already been demonstrated by Pont-Kingdon et al. (1994), Beagley et al. (1996), Finnerty and Martindale (1997), and Fautin and Smith (1997).

The results of our study show the striking effects of some details on the success of the DNA extraction protocol. The tissue type, maceration and digestion of tissue and amount of time allowed for proteinase $\mathrm{K}$ incubation were all essential for obtaining high-quality DNA.

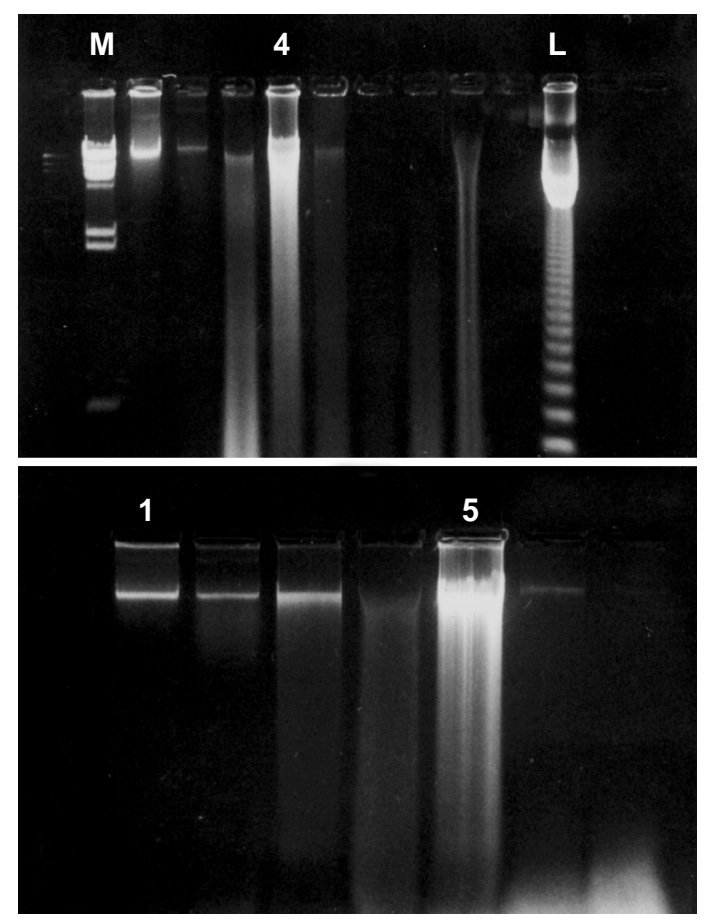

Figure 1 - Total DNA extracted from sea anemone tissues. Upper: M, molecular weight (digested with HindIII) and L, molecular weight 123 DNA ladder (GibcoBRL); lanes: 1 - Anthothoe chilensis, 2 - Bellactis ilkalyseae, 3 - Paratelmatactis sp., 4 - Anthopleura krebsi, 5 - Aiptasia pallida, 6-9 negative results by extraction using 24-h incubation with proteinase K. Bottom: 1 - A. chilensis (positive control), 2 - B. ilkalyseae, 3 - Paratelmatactis sp., 4 - Discosoma carlgreni, 5 - A. krebsi, 6 - C. dolosa. 


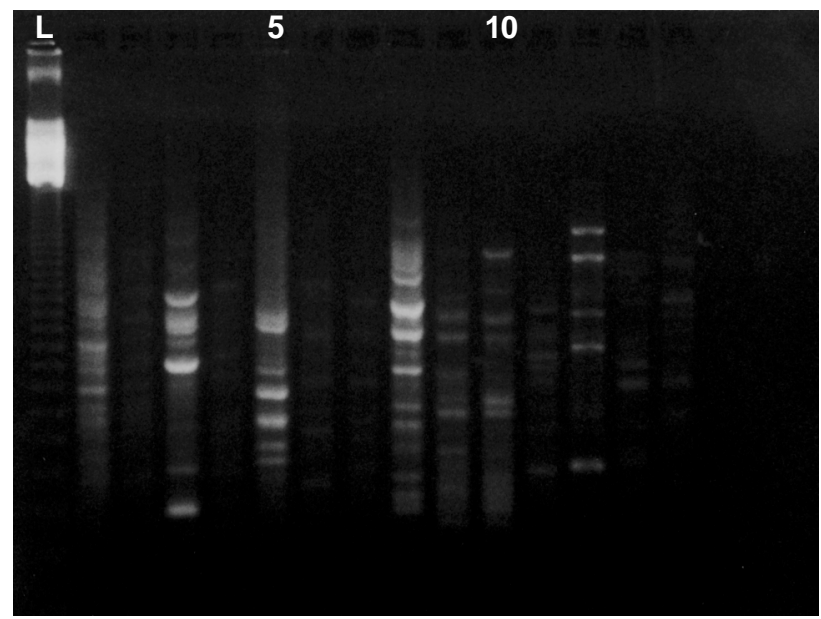

Figure 2 - PCR products by the SPAR technique using (GACA) ${ }_{4}$ as primers. L - Molecular weight 123 DNA ladder (GibcoBRL). Lanes: 1, 2 - Aiptasia pallida; 3 - Bellactis ilkalyseae; 4, 5 - Anthothoe chilensis (from Chile and Argentina, respectively); 6, 7 - Tricnidactis errans (from Brazil and Argentina, respectively); 8 - Anthopleura krebsi; 9, 10 - Haliplanella lineata; 11 - Discosoma carlgreni; 12 - Paratelmatactis sp.; 13 - Carcinactis dolosa.

Tissue type has been found to affect the success of DNA analyses of samples from plants (Chase and Hillis, 1991; Rogstad, 1992), birds (Seutin et al., 1991) and insects (Altschmied et al., 1997). We concluded that the dehydration of tissue until there is no trace of ethanol was the best solution to avoid interference in the reactions occurring during the extraction. Given the hard consistency of the tissue the use of liquid nitrogen to homogenize the samples was important to the success of DNA extraction. Chen et al. (1995) and Strassmann et al. (1996) state that grinding in liquid nitrogen is a simple and efficient means of isolating significant amounts of high-quality genomic DNA from tissues.

Duration and temperature of incubation with proteinase $\mathrm{K}$ also influenced the success of this method, and high incubation temperatures were inefficient in our study, although the temperature employed in many studies have ranged from $50^{\circ}$ to $65^{\circ} \mathrm{C}$ (McMillan et al., 1988; ten Lohuis et al., 1990; McMillan et al., 1991; Coffroth et al., 1992; Chen et al., 1995; France et al., 1996; Romano and Palumbi, 1997; Lopez and Knowlton, 1997; Lopez et al., 1999). Pilot experiments using a final concentration of $1 \mathrm{ng} / \mathrm{ml}$ of proteinase $\mathrm{K}$ at $37^{\circ} \mathrm{C}$ for $24-48-72 \mathrm{~h}$ revealed that the tissues were totally digested after $72 \mathrm{~h}$. Low concentrations of proteinase $\mathrm{K}$ failed to digest tissue at any temperature and incubation time. We, therefore, opted for a slow and gradual digestion method because of the hard consistency of the tissue.

To avoid any protein residues, we used double washes of phenol followed by repeated extractions with chloroform:isoamylalcohol (24:1). Since the intermediate phenol/chlorofom/isoamylalcohol steps described by Chen et al. (1995) did not affect the final quality of the samples these were omitted from our protocol.
The gradual decrease of the volume of recovered supernatant $(400 / 360 / 340 / 300 \mu \mathrm{l})$ guaranteed the high quality of the extracted product. After washing in $70 \%$ ethanol, DNA pellets are best dried by air for at least $24 \mathrm{~h}$ or dried in a vacuum centrifuge for 2-5 min. This step is particularly important for the success of PCR and sequencing reactions and prevents DNA degradation.

Samples of pure DNA are invaluable in studies of genetic evolution and systematic phylogenetic approaches using molecular data. The integrity of DNA is especially important for the amplification of large fragments. Figure 1 shows no signs of DNA degradation in the samples so that they could be used to amplify large fragments. High concentrations of extracted DNA (300-1400 ng/ $\mu \mathrm{l})$ have allowed us to begin a genetic stock of several species of sea anemone. The method described in this paper is a feasible method which allows the isolation of good DNA from tissues of sea anemones, and the protocol may also be applicable to other fleshy marine cnidarians.

\section{ACKNOWLEDGMENTS}

We are most grateful to Dr. L.F. de Almeida-Toledo (Universidade de São Paulo (USP), São Paulo), who has facilitated our study in the Laboratório de Ictiogenética no Instituto de Biociências da USP. We are also grateful to Dr. S.L. Romano (University of Guam, EUA) and Dr. S.R. Matioli (Universidade de São Paulo (USP), São Paulo) for critically reviewing the manuscript. We are indebted to Dr. A. Excoffon and P. Braga (Ciencias Marinas, Facultad de Ciencias Exactas y Naturales. UNMdP, Mar del Plata, Argentina) for collecting of specimens of A. chilensis and T. errans. Thanks are also due to M. Rivadeneira (Universidad de Chile) for the donation of specimens of A. chilensis. Financial support was provided by FAPESP (Fundação de Amparo à Pesquisa do Estado de São Paulo), Brazil, by a grant to the first author (No. 97/12232-9). Publication supported by FAPESP.

\section{RESUMO}

Descreve-se um método específico de extração de DNA para anêmonas-do-mar no qual o DNA total de oito espécies de anêmonas-do-mar e de uma espécie de Corallimorpharia foi obtido através de modificações de protocolos padrões de extração. A extração do DNA de anêmonas-do-mar tem sido dificultada pela consistência rígida do tecido e pela presença de zooxantelas simbiontes. A técnica descrita aqui é um meio eficaz para evitar problemas de contaminação de DNA e de obtenção de grandes quantidades de DNA íntegro, o qual pode ser usado em diferentes tipos de análises moleculares.

\section{REFERENCES}

Altschmied, J., Hornung, U., Schlupp, I., Gadau, J., Kolb, R. and Schartl, M. (1997). Isolation of DNA suitable for PCR for field and laboratory work. BioTechniques 23: 228-229.

Beagley, C.T., Macfarlane, J.L., Pont-Kingdon, G.A., Okada, N.A. and Wolstenholme, D.R. (1995). Mitochondrial genomes of Anthozoa (Cnidaria). In: Progress in Cell Research (Palmieri, F., Papa, S., Saccone, C. and Gadaleta, M.N., eds.) Vol. 5. Elsevier, Amsterdam, pp. 149-153. 
Beagley, C.T., Okada, N.A. and Wolstenholme, D.R. (1996). Two mitochondrial group introns in a metazoan, the sea anemone Metridium senile: One intron contains genes for subunits 1 and 3 of NADH dehydrogenase. Proc. Natl. Acad. Sci. USA 93: 5619-5623.

Bridge, D., Cunningham, W., Schierwater, B., de-Salle, R. and Buss, W. (1992). Class-level relationships in the phylum Cnidaria: evidence from mitochondrial genome structure. Proc. Natl. Acad. Sci. USA 89: 87508753.

Bridge, D., Cunningham, C.W., DeSalle, R. and Buss, L.W. (1995). Classlevel relationships in the phylum Cnidaria: molecular and morphological evidence. Mol. Biol. Evol. 12: 679-689.

Chase, M.W. and Hillis, H.H. (1991). Silica gel: an ideal material for field preservation of leaf samples for DNA studies. Taxon 40: 215-220.

Chen, C.A., Odorico, D.M., Lohuis, M.T., Veron, J.E.N. and Miller, D.J. (1995). Systematic relationships within the Anthozoa (Cnidaria: Anthozoa) using the 5' -end of the 28S rDNA. Mol. Phylogenet. Evol. 4: 175-183.

Christen, R., Ratto, A., Baroin, A., Perasso, R., Grell, K.G. and Adoutte, A. (1991). An analysis of the origin of metazoans, using comparisons of partial sequences of the 28S RNA, reveals an early emergence of triploblasts. EMBO J. 10: 499-503.

Coffroth, M.A., Lasker, H.R., Diamond, M.E., Bruenn, J.A. and Bermingham, E. (1992). DNA fingerprints of a gorgonian coral: a method for detecting clonal structure in a vegetative species. Mar. Biol. 114: 317-325.

Fautin, D.G. and Smith, D.R. (1997). Clonality as a taxonomic character of actinian species. Proceedings of the 8th International Coral Reef Symposium, Panamá 2: 1609-1612.

Finnerty, J.R. and Martindale, M.Q. (1997). Homeboxes in sea anemones (Cnidaria; Anthozoa): a PCR-based survey of Nematostella vectensis and Metridium senile. Biol. Bull. 193: 62-76.

Folmer, O., Black, M., Hoeh, W., Lutz, R. and Vrijenhoek, R. (1994). DNA primers for amplification of mitochondrial cytochrome c oxidase subunit I from diverse metazoan invertebrates. Mol. Mar. Biol. Biotechnol. 3: 294-299.

France, S.C., Rosel, P.E., Agenbroad, J.E., Mullineaux, L.S. and Kocher, T.D. (1996). DNA sequence variation of mitochondrial large-subunit rRNA provides support for a two subclass organizations of the Anthozoa (Cnidaria). Mol. Mar. Biol. Biotechnol. 5: 15-28.

Gupta, M., Chyi, Y.-S., Romero-Severson, J. and Owen, J.L. (1994). Amplification of DNA markers from evolutionary diverse genomes using single primers of simple-sequence repeats. Theor. Appl. Genet. 89: 998-1006.

Hori, H. and Satow, Y. (1991). Dead-end evolution of the Cnidaria as deduced from 5S ribosomal RNA sequences. Hydrobiologia 216/217: 505-508.

Lopez,J.V. and Knowlton, N. (1997). Discrimination of species in the Montastrea annularis complex using multiple genetic loci. Proceedings of the 8th International Coral Reef Symposium, Panamá 2: 1613-1618.

Lopez, J.V., Kersanach, R., Rehner, S.A. and Knowlton, N. (1999). Molecular determination of species boundaries in corals: genetic analysis of the Montastrea annularis complex using amplified fragment length polymorphisms and a microsatellite marker. Biol. Bull. 196: 80-93.

McCommas, S.A. (1991). Relationships within the family Actiniidae (Cnidaria, Actiniaria) based on molecular characters. Hydrobiologia 216/217: 509-512.
McMillan, J., Yellowlees, D., Heyward, A., Harrison, P. and Miller, D.J. (1988). Preparation of high molecular weight DNA from hermatypic corals and its use for DNA hybridization and cloning. Mar. Biol. 98 : 271-276.

McMillan, J., Mahony, T., Veron, J.E.N. and Miller, J. (1991). Nucleotide sequencing of highly repetitive DNA from seven species in the coral genus Acropora (Cnidaria: Scleractinia) implies a division contrary to morphological criteria. Mar. Biol. 110: 323-327.

Odorico, D.M. and Miller, D.J. (1997). Internal and external relationships of the Cnidaria: implications of primary and predicted secondary structure of the $5^{\prime}$-end of the 23S-like rDNA. Proc. R. Soc. Lond. B. 264: 77-82.

Palumbi, S.R. (1996). Nucleic acids II: the polymerase chain reaction. In: Molecular Systematic (Hillis, D.M., Craig, M. and Mable, B.K., eds.). 2nd edn. Sunderland, Massachusetts, 205-247.

Pont-Kingdon, G.A., Beagley, C.T., Okimoto, R. and Wolstenholme, D.R. (1994). Mitochondrial DNA of the sea anemone, Metridium senile (Cnidaria): prokaryote-like genes for tRNA-f-Met and small-subunit ribosomal RNA, and standard genetic specificities for AGR and ATA codons. J. Mol. Evol. 39: 387-399.

Rogstad, S.H. (1992). Saturated NACl-CTAB solution as a means of field preservation of leaves for DNA analyses. Taxon 41: 701-708.

Romano, S.L. and Palumbi, S.R. (1997). Molecular evolution of a portion of the mitochondrial $16 \mathrm{~S}$ ribosomal gene region in scleractinian corals. $J$. Mol. Evol. 45: 397-411.

Saiki, R.K., Gelfand, D.H., Stoffel, S., Scharf, S.J., Higuchi, R., Horn, G.T., Mullis, K.B. and Erlich, H.A. (1988). Primer-directed enzymatic amplification of DNA with a thermostable DNA polymerase. Science 239: 487-491.

Seutin, G., White, B.N. and Boag, P.T. (1991). Preservation of avian blood and tissue samples for DNA analyses. Can. J. Zool. 69: 82-90.

Shick, J.M. (1991). A Functional Biology of Sea Anemones. Chapman and Hall, London, pp. 395.

Shure, M., Wessler, S. and Fedoroff, N. (1983). Molecular identification and isolation of the Waxz locus in maize. Cell 35: 225-233.

Strassmann, J.E., Solís, C.R., Peters, J.M. and Queller, D.C. (1996). Strategies for finding and using highly polymorphic DNA microsatellite loci for studies of genetic relatedness and pedigrees. In: Molecular Zoology (Ferraris, J.D. and Palumbi, S.R., eds.). Wiley-Liss, New YorK, 163 180

ten Lohuis, M., Alderslade, P. and Miller, D.J. (1990). Isolation and cloning of DNA from somatic tissue of soft corals (Cnidaria: Octocorrallia). Mar. Biol. 104: 489-492.

Veron, J.E.N., Odorico, D.M., Chen, C.A. and Miller, D.J. (1996). Reassessing evolutionary relationships of scleractinian corals. Coral Reefs 15: $1-9$.

Winnepenninckx, B., Backelgau, T. and De Wachter, R. (1993). Extractions of high molecular weight DNA from molluscs. Trends Genet. 9: 407.

Wolstenholme, D.R. (1992). Animal mitochondrial DNA: Structure and evolution. Int. Rev. Cytol. 141: 173-216.

Wolstenholme, D.R. and Fauron, C.M.R. (1976). A partial map of the circular mitochondrial genome of Drosophila melanogaster: location of EcoRIsensitive sites and the adenine-thymine-rich region. J. Cell. Biol. 71: $434-448$.

(Received December 15, 1999) 